\title{
Luokasta utopiaan: Erik Olin Wrightin myöhäistuotannosta
}

Keijo Lakkala, yhteiskuntatieteiden ja filosofian laitos, Jyväskylän yliopisto

\begin{abstract}
Abstrakti
Katsausartikkelissa tarkastellaan yhdysvaltalaisen marxilaissosiologi Erik Olin Wrightin niin sanottuihin todellisiin utopioihin kohdistunutta tutkimusta. Artikkelissa avataan sekä sitä, kuinka Wrightin todellisen utopian käsite tulisi ymmärtää, että sitä, kuinka hänen oma utopiansa eli "sosiaalinen sosialismi" voisi olla mahdollinen ja millaiset tosimaailman kokeilut hänen mukaansa ennakoivat ja prefiguroivat tätä utopiaa. Lisäksi artikkelissa eritellään Wrightin käsityksiä antikapitalismin strategioista ja näiden myötä siitä, millä tavalla sosiaalisen sosialismin utopia olisi saavutettavissa. Artikkeli keskittyy erityisesti kahteen Wrightin myöhäistuotannon teokseen - Envisioning Real Utopias (2010) ja How to Be an Anticapitalist in the 21st century (2019) - ja vuonna 2017 Wrightin Suomen-vierailun yhteydessä tehtyyn haastatteluun.
\end{abstract}

\section{Johdanto}

Vuoden 2019 tammikuussa kuollut yhdysvaltalaissosiologi Erik Olin Wright tuli tunnetuksi erityisesti hänen yhteiskuntaluokkia koskevista tutkimuksistaan. Luokkia koskevissa teorioissaan Wright hyödynsi laajasti erilaisia porvarillisen sosiologian teoriaperinteitä, mutta samalla hän halusi pitää kiinni (niin sanotun analyyttisen marxismin kautta tulkitun) marxilaisuuden "perusasetuksista" (Wright, Lakkala \& Pyykkönen 2018). Tämä yhdistelmä ei ollut itsestään selvä varsinkaan 1970-luvulla, kun Wright alkoi kehittää luokkateoriaansa. Marxilaisuus ja sosiologia nähtiin tuolloin paitsi toisilleen vihamielisinä myös keskinäisinä kilpailijoina. Wright oli kuitenkin valmis hyödyntämään myös ei-marxilaisten teoreetikkojen työtä luokkateoriaansa 
kehittäessään. Karl Marxin ohella etenkin Max Weberillä ja Pierre Bourdieu'llä on tärkeä sija Wrightin ajattelussa.

Avoimuudella on ollut hedelmällisiä seuraamuksia. Ilman tätä ajattelun avarrusta Wright olisi tuskin koskaan kehittänyt ristiriitaisen luokkaposition käsitettä, jota voidaan pitää Wrightin yhtenä keskeisistä teoreettisista innovaatioista. Käsitteen taustalla olevan argumentin voi ilmaista seuraavasti. Perinteisestä marxilaisesta teoriasta poiketen luokat eivät kapitalistisessa yhteiskunnassa jakaannu yksinkertaisesti kahteen eli omistavaan ja ei-omistavaan luokkaan, vaan näiden kahden luokan väliin kehittyy erilaisten historiallisten prosessien kautta ristiriitaisia luokkapositioita, joiden pohjalle puolestaan kehittyy varsin ristiriitaisia luokkaintressejä (ks. Wright 1985, 43-44). Näin esimerkiksi keskiluokka ei näyttäydy omana luokkanaan porvariston ja työväenluokan luokan välissä, vaan joukkona ristiriitaisia luokkapositioita, joissa on piirteitä sekä porvaristosta että työväenluokasta.

Wrightin luokkaa koskevia tutkimuksia tunnetaan Suomessa varsin hyvin, mutta hänen myöhäisempää, niin sanottuja todellisia utopioita käsittelevää tutkimusta ei Suomessa ole kovinkaan laajasti nostettu esille. Wright piti utopian ja sosialismin teemoja ajattelussaan jopa luokkaa tärkeämpinä teemoina, vaikka hän jatkoikin luokkaa koskevia tutkimuksiaan loppuun asti (hänen viimeinen luokkaa koskeva teoksensa, esseekokoelma Understanding Class julkaistiin vuonna 2017). Luokan piti olla Wrightille ajattelun sivujuonne, mutta luokkiin liittyvien kysymysten kompleksisuus vei häneltä enemmän aikaa kuin oli alkujaan tarkoitus. Utopian ja sosialismin teemat eivät silti olleet hänelle milloinkaan toissijaisia. Vuonna 2017 antamassaan haastattelussa Wright korostaa nimenomaan yhteiskunnallisen muutoksen ja kapitalismin vaihtoehtojen teemojen perustavuutta hänen ajattelussaan:

Eniten välitin ja innostuin 70-luvulla valtion, yhteiskunnallisen muutoksen ja kapitalismin vaihtoehtojen teemoista. Aioin vain vähän siivota luokkateorian sotkuja, puutarhuroida maiseman kuntoon, jotta voisin tutkia näitä aiheita. En koskaan ajatellut siitä tulevan tällaista päähänpinttymää”(Wright, Lakkala \& Pyykkönen 2018).

Tässä artikkelissa esittelen Wrightin todellisia utopioita koskevaa tutkimusta ja sen myötä myös hänen Suomessa vähemmän tunnettua myöhäistuotantoaan. 
Etenen seuraavassa järjestyksessä. Ensin tarkastelen Wrightin tapaa ymmärtää utopian käsite. Tämän jälkeen siirryn erittelemään Wrightin omaa erityistä utopiaansa: sosialismia, joka Wrightin sanoin ottaa "sosiaalisen" sosialismissa tosissaan (ks. esim. Wright 2010a, 79-80). Lopuksi tarkastelen Wrightin viimeiseksi jääneen kirjan How to Be an Anticapitalist in the 21st Century (2019) keskeistä teemaa: sosialismiin siirtymisen strategiaa (ks. myös Wright 2016). Tätä teemaa Wright oli käsitellyt jo aiemmin esimerkiksi vuoden 2010 teoksessaan Envisioning Real Utopias, mutta viimeisessä teoksessaan Wrightin aihetta koskeva teoretisointi terävöityy aiempaan nähden. Näiden kahden kirjan välillä on nähtävissä selkeää jatkuvuutta. Alkujaan Wright ajatteli tekevänsä jonkinlaista yleistajuista tiivistelmää vanhemmasta teoksestaan, mutta päätyi lopulta tekemään sille "jatko-osan" (Wright 2019, xi). Wright ei itse nähnyt tuotannossaan varsinaisia katkoksia utopiateemojen suhteen (Wright, Lakkala \& Pyykkönen 2018). Tästä syystä käytän molempia teoksia tasaveroisesti selventämään Wrightin myöhäisen ajattelun teemoja ja argumentteja.

\section{Todellisen utopian käsitteestä}

Wrightin koko myöhäistuotannon keskeinen käsite on todellisen utopian (real utopia) käsite. Wright määrittelee utopian moraalisesti inspiroituneiksi uudenlaisen yhteiskunnan suunnitelmiksi (Wright 2010b, 5), jolla on tärkeä merkitys kaikessa maailman muuttamiseen tähtäävässä toiminnassa. Perinteisestä marxismista poiketen Wright ei ajattele, että yhteiskunnallista muutosta voitaisiin saada aikaiseksi vetoamalla pelkästään ihmisten taloudellisiin tai luokkaintresseihin. Hänen mukaansa on selvä tosiasia, että ihmisiä liikuttaa taloudellisten ja luokkaintressien lisäksi myös moraaliset huolenaiheet. Joskus ihmiset toimivat luokkaintressejään vastaan moraalisista syistä (Wright 2019, 7). Yhtenä esimerkkinä henkilöstä, joka moraalisin syin toimi omia luokkaintressejään vastaan, Wright $(2019,8)$ esittää Karl Marxin työtoverin, Friedrich Engelsin, joka oli rikkaan kapitalistin poika, mutta joka vastoin omia luokkaintressejään tuki täydestä sydämestään kapitalismin vastaisia liikkeitä. Myöskään Yhdysvaltojen pohjoisten osavaltioiden orjuuden lakkauttamista vaatineet abolitionistit eivät Wrightin mukaan toimineet puhtaasti omien 
luokkaintressiensä mukaisesti, vaan heitäkin motivoi moraalinen uskomus, jonka mukaan orjuus oli yksinkertaisesti väärin ja tuomittavaa (Wright 2019, 8).

Wrightille utopia merkitsee moraalisesti inspiroitunutta, ideaalista kuvausta toivotusta yhteiskunnasta. Tätä se tarkoitti hänelle jo vuonna 1971, jolloin hän määritteli utopian "parhaaksi mahdolliseksi yhteiskunnaksi, jota todelliset ihmiset asuttavat" (Wright 1971, 2). Jo tuolloin Wright ymmärsi, että tämä paras mahdollinen yhteiskunta ei voi toteutua sellaisenaan, vaan voimme korkeintaan identifioida niitä institutionaalisia tekijöitä, jotka estävät tai edistävät tuon utopian saavuttamista (Wright 1971, 11). Utopia on ja pysyy horisontissa, mutta emme voi sitä varsinaisesti koskaan saavuttaa. Todellinen maailma ja utopia ovat ja pysyvät jännitteisessä suhteessa toisiinsa. Tätä jännitettä ideaalien ja todellisuuden välillä myös Wrightin "todellisen" utopian käsite pyrkii tavoittamaan.

Utopian käsitteestä puhuttaessa erilaiset realismin ja idealismin "välistä" kulkevat näkemykset eivät tietenkään ole ainutlaatuisia. Kuuluisimpana esimerkkinä utopioiden "todellisuuden" puolestapuhujana voidaan pitää marxilaisfilosofi Ernst Blochia, joka kirjoituksissaan käytti "konkreettisen utopian" käsitettä puhuessaan sellaisista utopioista, jotka pelkän ideaalin sijaan olivat todellisuudessa itsessään piileviä latentteja mahdollisuuksia, joiden toteutumiseen historialliset tendenssit vaikuttavat (ks. Bloch 1985 \& 1986). Toisena esimerkkinä realismin ja idealismin yhdistämiseen pyrkivästä teoretisoinnista voidaan pitää liberalistifilosofi John Rawlsin ajattelua sekä etenkin tämän esittämää "realistisen utopian" (Rawls 1999, 6) ajatusta.

Yhdistäessään realismin ja idealismin Wrightin tarkoitus on paitsi ottaa huomioon olemassa olevan maailman utopioiden toteutumista koskevat rajoitteet, niin myös provosoida pohtimaan ihmisten ideaalien toteutumiseen liittyviä mahdollisia ristiriitoja ja tragedioita (Wright, Lakkala \& Pyykkönen 2018). Ihmisten toiminnalla on aina tarkoittamattomia seurauksia ja todellisten utopioiden tarkoitus onkin pyrkiä kartoittamaan niitä jo ennalta, jotta erilaisilta katastrofeilta ja tragedioilta vältyttäisiin. Todellisen utopian "todellisuus" merkitsee Wrightillä siis joustavuutta suhteessa todellisuuden tarjoamiin mahdollisuuksiin ja rajoituksiin. Utopioiden on muututtava, niiden on oltava joustavia ja dynaamisia. Niiden on oltava avoimia ja institutionaalisesti pluralistisia (ks. Wright 2010b, 368). 
Wrightin todellisen utopian käsitteen voidaan katsoa liittyvän perinteiseen valistushumanismin käsityksiin utopiasta. Esimerkiksi sosiologi Karl Mannheim on klassikkoteoksessaan Ideology and Utopia $(1979,197)$ kirjoittanut "liberaalis-humanitaarisesta" utopiatyypistä, jonka keskeisiin piirteisiin kuuluu utooppisen päämäärän formaalisuus: utopia on tämänkaltaiselle utopiakäsitykselle muodollinen päätepiste, jota voimme vain approksimoida, sekä mittatikku, jota vasten todellista maailmaa mitataan. Myös Wrightille utopia on tällainen regulatiivinen idea:

[Kristillisyydessä] Jeesuksen funktio on antaa ihmisille täydellisyyden idea, vaikka nämä tietävätkin, etteivät he koskaan kykene saavuttamaan sitä. Aina voi verrata itseään Jeesukseen ja kysyä: 'Kuinka lähelle olen pääsemässä?' Se on ihmisen toimintaa sääntelevä idea. - - Mielestäni utopia toimii eräänlaisena yhteiskuntatutkimuksen Jeesuksena" (Wright, Lakkala \& Pyykkönen 2018).

Todellisen utopian käsite asettaa historiallisen todellisuuden ja siihen vertautumaan tarkoitetun mittatikku-utopian vastakkain. Todellisuudesta kohti utopiaa suuntautuminen ei Wrightillä ole mitään suoraviivaista edistystä. Toisinaan pääsemme lähemmäksi asettamaamme päämäärää, mutta toisinaan ajaudumme siitä kauemmaksi. Joskus puolestaan olemme täysin hukassa. Wright käyttääkin nykyisyydestä kohti utopiaa suuntautumisesta kompassimetaforaa:

Aivan kuin lähtisimme matkaan oppaanamme vain kompassi, mutta ilman karttaa: tiedämme kyllä suunnan johon kuljemme, mutta emme koko reittiä lähtöpisteestä määränpäähän. Tässä on tietenkin riskinsä: tiellemme voi osua rotkoja, joita emme voi ylittää tai ennalta-arvaamattomia esteitä, jotka pakottavat meidät hakemaan uutta suuntaa. (Wright 2010a, 75.)

Wrightin käsitteistössä todellisen utopian käsite viittaa tietynlaiseen realismiin, muttei rajoitu siihen. Käsite viittaa myös olemassa oleviin tosimaailman pyrkimyksiin toteuttaa utooppisia ihanteita. Tosimaailman utooppisia pyrkimyksiä voidaan tutkia sosiologian keinoin. Vuonna 1991 alkaneessa The 
Real Utopias -projektissa tutkittiin Wrightin johdolla tosimaailman utooppisia pyrkimyksiä sekä erilaisia todellisiin utopioihin liittyviä kysymyksiä markkinasosialismin mahdollisuudesta, sukupuolten välisestä tasa-arvosta ja tulonjaosta alkaen. Vuodesta 1995 lähtien projektin tuloksia on julkaistu kirjasarjana. Sarjassa on tähän mennessä julkaistu kuusi teosta. Vuonna 2010 julkaistiin projektin tähänastinen huipentuma, Envisioning Real Utopias, jota Wrightin läheinen työtoveri (ja kiistakumppani), sosiologi Michael Burawoy (2019) on pitänyt yhtenä Wrightin pääteoksista. Utooppisessa pääteoksessaan Wright pyrki paitsi muotoilemaan koko todellisten utopioiden tutkimusohjelmansa peruslinjat myös argumentoimaan yhden moraalisesti inspiroituneen vision sosialismin - puolesta.

\section{Sosiaalinen sosialismi}

Wrightin visio sosialismista tähtää kahteen laajaan normatiiviseen päämäärään: poliittiseen ja sosiaaliseen oikeudenmukaisuuteen. Poliittisella oikeudenmukaisuudella Wright tarkoittaa ihmisten tasavertaista mahdollisuutta osallistua elämäänsä koskettavaan päätöksentekoon. Sosiaalisella oikeudenmukaisuudella Wright puolestaan tarkoittaa sellaista yhteiskunnallista tilaa, jossa kaikilla ihmisillä on tasa-arvoinen mahdollisuus päästä käsiksi kukoistavan elävän materiaalisiin ja sosiaalisiin edellytyksiin. (Wright 2010b, 12.)

Teoksessaan How to Be an Anticapitalist in the 21st Century Wright nostaa esille kolme sosialismin kannalta tärkeää arvorypästä: tasa-arvo/reiluus, demokratia/vapaus sekä yhteisö/solidaarisuus (Wright 2019, 9-22). Yhteiskunnan voidaan katsoa olevan tasa-arvoinen ja reilu silloin kun se on sosiaalisesti oikeudenmukainen eli silloin kun se tarjoaa kaikille mahdollisuuden päästä käsiksi kukoistavan elämän materiaalisiin ja sosiaalisiin edellytyksiin. Yhteiskunnan voidaan puolestaan katsoa olevan demokraattinen ja vapaa mikäli se toteuttaa yllä mainitun poliittisen oikeudenmukaisuuden periaatteen: täysin demokraattisessa yhteiskunnassa kaikilla ihmisillä on laaja mahdollisuus päästä käsiksi osallistumaan merkityksellisellä tavalla päätöksentekoon niistä asioista, joilla on vaikutuksia heidän elämiinsä. Lisäksi yhteiskunnan voidaan katsoa olevan yhteisöllinen ja solidaarinen, kun ihmiset eivät tässä yhteiskunnassa toimi yhteistyössä toistensa kanssa vain oman etunsa vuoksi, vaan 
myös siksi, että he ovat aidosti sitoutuneita edistämään toisten hyvinvointia ja katsovat sen myös moraaliseksi velvollisuudekseen. Näiden kolmen arvoryppään voidaan katsoa tarjoavan sosialistisen utopian moraalisen sisällön sekä sen mittapuun, jota vasten todellisuutta arvioimme. Koska nämä arvoryppäät toimivat kuitenkin vielä varsin abstraktilla tasolla, jää sosialismin institutionaalinen olemus varsin avonaiseksi. Sosialismin on tultava todelliseksi.

Kuten muutkin utopiat, myös sosialismi voidaan ymmärtää "todelliseksi utopiaksi" kahdella tavalla. Ensinnäkin se voidaan utopiana muotoilla siten, että kun yllä esiteltyjä normatiivisia ideaaleja pyritään tosimaailmassa institutionaalisella tasolla toteuttamaan, otetaan huomioon normatiivisen toivottavuuden (desirability) lisäksi huomioon se, mikä on toteuttamiskelpoista (viability) ja ylipäätään saavutettavissa olevaa (achievability). Tämän realisminäkökulman lisäksi sosialismi voidaan ymmärtää todelliseksi utopiaksi myös siten, että paikannamme jo nykyisessä yhteiskunnassa sosialismin normatiivisia tavoitteita toteuttamaan pyrkiviä tosimaailman utooppisia hankkeita. Tältä osin Wrightin ajattelu linkittyy laajempaan keskusteluun prefiguraatiosta. Prefiguraatiolla viitataan yleensä paitsi pyrkimyksiin elää utopia todeksi jo tässä ja nyt, niin myös ajatukseen keinojen ja päämäärien tavoitellusta yhteensopivuudesta yhteiskunnallisessa toiminnassa. Prefiguraation idealla ja käsitteellä on pitkä historia erityisesti anarkistisessa teoriassa (ks. esim. Kinna 2016 \& Franks 2018), mutta teema on ollut esillä myös marxilaisissa keskusteluissa, joissa viitataan myös Wrightin ajatteluun (ks. Monticelli 2018).

Teoksessaan Envisioning Real Utopias Wright nostaa esille kolme sosialismin normatiivisia ideaaleja toteuttamaan pyrkivää kokeilua (Wright 2010b, 12). Ensimmäinen esimerkki sosialistisesta todellisesta utopiasta ovat erilaiset osuuskuntatoiminnalliset liikkeet. Tarkempana esimerkkinä osuuskuntatoiminnasta Wright (emt., 240) mainitsee Mondragon-osuuskuntayhteenliittymän Baskimaan itsehallintoalueella Espanjassa. Toisena esimerkkinä voidaan Wrightin mukaan pitää verkkotietosanakirja Wikipediaa. Wikipedia toteuttaa vapaaehtoista, avointa ja tasa-arvosta, suoriin ja deliberatiivisiin, demokraattisiin ihmisten välisiin suhteisiin perustuvaa talousmallia (emt., 195-199). Sekä osuuskuntien että Wikipedian voidaan katsoa ilmentävän sosialismille keskeisiä poliittisen ja sosiaalisen oikeudenmukaisuuden periaatteita. 
Kolmantena esimerkkinä Wright pitää perustuloa, jolla voisi riittävän suurena olla merkittäviä seurauksia kapitalistisiin luokkasuhteisiin. Perustulolla on vaikutusta luokkasuhteisiin kolmella tavalla. Ensiksi, perustulo antaa työvoimalle neuvotteluvaltaa, koska se mahdollistaa tarjotusta työstä kieltäytymisen. Jos työ ei puitteiltaan, palkkaukseltaan tai etuuksiltaan miellytä, voi työläinen kieltäytyä kaupasta ja etsiä parempaa sopimusta. Tällöin vastuu työn mielekkyydestä siirtyy entistä voimakkaammin työnantajan taholle. Toiseksi, edellisestä seuraten, työvoimalla on myös kollektiivisesti vahvempi asema yhteiskunnassa. Kolmanneksi, perustulo voidaan tulkita eräänlaiseksi lakkokassaksi "vailla varauksia ja loppuun kulumisen vaaraa" (Wright 2010b, 82). Perustulo ilmentää ensisijaisesti sosialismille ominaisen sosiaalisen oikeudenmukaisuuden periaatetta. Perustulolla olisi tällä tavoin koko työväenliikettä vahvistava vaikutus. Ammattiyhdistysliikkeet ovat vastustaneet perustuloa sillä perusteella, että sen on nähty tukevan laiskottelijoita ahkerien työläisten kustannuksella. On myös pelätty, että jos perustulo otetaan käyttöön, työntekijät eivät enää tarvitsisi ammattiliittoja laisinkaan. Wrightin mielestä tämä pelko on kuitenkin perusteeton, sillä perustulo tuo työtaisteluun merkittävää lisäkapasiteettia, mikä on huomattavasti suurempi etu kuin kollektiivisen organisoitumisasteen marginaalisesta vähenemisestä koituva haitta. (Wright 2010a, 82.)

Perustuloa voidaan myös potentiaalisesti "pitää massiivisena yhteiskunnallisen lisäarvon siirtona kapitalistiselta markkinasektorilta sosiaalisen talouden hyväksi, siirtymänä pääoman kasautumisen logiikasta kohti kasautumisen tapaa, jota voidaan kutsua sosiaaliseksi: tämä olisi yhteiskunnan tarvelähtöisen taloudellisen toiminnan itseorganisoitumiskyvyn kasautumista” (Wright 2010a, 83). Perustulo saattaisi kyllä haitata esimerkiksi infrastruktuurien kehittämistä ja ylläpitoa jonkin verran (perustulo ei merkitse tulonsiirtoa ei-työvoimapainotteisille talouden alueille), mutta vastapainoksi se tukisi poliittista, yhteisöllistä ja kulttuurista toimintaa ennen näkemättömällä tavalla. Tämä puolestaan voisi potentiaalisesti edesauttaa myöhempiä pyrkimyksiä kohti sosialismia. Perustulo on vain sosialismin lähiennakointia, ei vielä sosialismia itseään. Vaikka perustulo osaltaan ilmentääkin sosialismin sosiaalisen oikeudenmukaisuuden periaatetta, ei se yksinään tätä periaatetta täysin toteuta. Voitaisiin sanoa, niin perustulo kuin osuuskuntatoiminta ja Wikipediakin prefiguroivat, ennakoivat sosialistista utopiaa, jossa sekä 
sosiaalinen että poliittinen oikeudenmukaisuus olisivat täysin toteutuneet (ks. Wright 2012, 21).

Wright tavoittelee sosialismia, jonka hän katsoo ideaalimuodossa toteuttavan sekä sosiaalisen että poliittisen oikeudenmukaisuuden. Institutionaalisella tasolla sosialismi on hänelle kuitenkin vain yksi ideaalityyppi, jonka hän erottaa kapitalismin ja etatismin (valtiojohtoisuuden) ideaalityypeistä. Näiden kolmen ideaalityypin välisten kontrastien avulla Wright pyrkii täsmentämään suunnistuksellisia periaatteita sosialistiselle "kompassille". "Sosiaalinen" tulee ottaa vakavissaan sosialismista puhuttaessa. Sosialismi ei tarkoita yksityisomistusta (mitä kapitalismi on) eikä valtio-omistusta (mitä etatismi on), vaan sosiaalista, vertaisten kesken tapahtuvaa, talouteen suuntautuvaa vallankäyttöä. Sosialismi on Wrightille oikeastaan vain toinen termi syvälle käyvälle ja pitkälle viedylle, talouteen asti ulottuvalle demokratialle.

Toisin kuin kapitalismi, jolle tyypillisin valtamuoto pohjautuu taloudellisia resursseja kontrolloimaan tähtäävälle taloudelliselle vallalle, ja etatismi, jossa dominoiva valtamuoto on hallitsemiselle sekä sääntöjen laatimiselle ja toimeenpanemiselle perustuva poliittinen valta, pohjautuu sosialismi "sosiaaliselle vallalle". Sloganeita käyttäen: siinä missä kapitalismi perustuu lahjonnalle ja etatismi pakottamiselle, perustuu sosialismi vakuuttamiselle. Sosiaalisella vallalla tarkoitetaan valtaa, joka on juurtunut kykyyn mobilisoida ihmisiä yhteistoiminnalliseen, vapaaehtoiseen kollektiiviseen toimintaan kansalaisyhteiskunnassa (Wright 2010b, 121). Kansalaisyhteiskuntaa ei tässä nähdä pelkästään aktiivisuuden, sosiaalisuuden ja kommunikaation, vaan myös todellisen vallan areenana. Wright (2010b, xviii) pyrkiikin ajattelemaan sosialismin uudelleen juuri "sosiaalisen vallan" ja radikaalidemokratian käsitteillä.

Vaikka Wright identifioituu sosialistiksi ja puhuu sosialismin puolesta, hän ei kannata suunnitelmataloutta, vaan näkee jonkinlaiset markkinat välttämättöminä myös sosialismissa. Niin sanotun "osallisuustalouden" ${ }^{\text {(Parecon) }}$ kehittäjän, taloustieteilijä Robin Hahnelin kanssa käydyssä debatissa Wright asettuu "sympaattisen kriitikon" asemaan (Hahnel \& Wright 2016). Hän hyväksyy Hahnelin keskeiset demokraattiset arvot ja tavoitteet, mutta katsoo suunnitelmatalouden olevan kattavana järjestelmänä hyvinkin ongelmallinen. Wrightin mukaan osallisuustaloudelliseen suunnitteluun kuuluu ihmisten kulutuksen suunnittelu esimerkiksi vuoden mittaisella ajanjaksolla (Wright, Lakkala \& Pyykkönen 2018). Jokainen täyttää inventaariolomakkeen 
kaikista asioista, joita he aikovat kuluttaa seuraavan vuoden aikana. Tämä on osallisuustaloudellisen, demokraattisen suunnitteluprosessin lähtökohta. Tämä on kuitenkin Wrightin mukaan ongelmallista, koska kenelläkään ei voi olla ennakolta tietoa siitä mitä tulee vuoden aikana tarvitsemaan. Markkinat hoitavat tällaiset tarpeet Wrightin mukaan paljon sujuvammin ja joustavammin. Markkinoilla on suunnittelusta puuttuvan virheellisyyden sijaan muita ongelmia (Wright, Lakkala \& Pyykkönen 2018):

Ongelmallista on jako voittajiin ja häviäjiin eli kasautuvan hyödyn tuottaminen, mistä seuraa vallan kumuloitumista. Toisin sanoen ne tuottavat pääoman kasautumista, joka on vallan muoto. Tämä asia tulee korjata. Tarvitaan sosialistista markkinataloutta tai osuustoiminnallista markkinataloutta ja riittävän vaikutusvaltaisia valtioinstituutioita, jotta voidaan demokraattisesti ja menestyksekkäästi säätää rajoituksia tälle vallan kasautumiselle. Esimerkki tällaisista rajoituksista on progressiivinen verotus, joka verottaa erityisesti suureksi nousevaa hyötyä ja muut vastaavat säätelevät mekanismit.

\section{Sosialistien utopian strategiat}

Wrightin sosialismi merkitsee ennen muuta radikaalidemokraattista, kansalaisyhteiskunnasta kasvavaa, talouteen suuntautuvaa sosiaalista valtaa. Tällainen käsitys sosialismista saa helposti epäilemään Wrightia anarkistiksi. Kansalaisyhteiskunnan spontaania organisoitumista taloudelliseen toimintaan pidetään usein anarkistiseen poliittiseen ajatteluun liittyvänä ideana. Wrightin mukaan yhtäläisyyksiä anarkismin ja hänen ajattelunsa välillä onkin, mutta keskeinen ero Wrightin "sosiaalisen" sosialismin ja anarkismin välillä koskee strategisia kysymyksiä. Anarkismista poiketen Wright hyväksyy valtion keskeiseksi osaksi kapitalismin vastaista strategiaa. Sosialismi vaatii avukseen valtiota (Wright 2010b, 146).

Wrightin teoksen Envisioning Real Utopias (2010b, 308-365) pohjalta tätä ajatusta voidaan kuvata raottavan (interstitial) ja symbioottisen (symbiotic) todellisen utopian toteuttamisen strategian yhdistelmäksi. Symbioottinen strategia viittaa klassiseen sosialidemokraattiseen strategiaan, jossa tavoitellaan 
sosialismia asteittaisin, mutta melko kokonaisvaltaisin reformein. Wright pyrkii visiossaan yhdistämään symbioottiseen strategiaan raottavan strategian, jonka avulla on tarkoitus nakertaa kapitalismia pala kerrallaan erilaisten vaihtoehtoisten käytäntöjen avulla. Yhtäältä on siis luotava ruohonjuuritason kokeilevaa, "raottavaa" toimintaa, mutta toisaalta on myös tuettava "symbioottisesti" sellaisia valtiollisia reformeja, jotka edesauttavat raottavan toiminnan leviämistä ja syvenemistä. On tuettava niin sanottuja "ei-reformistisia reformeja" (Gorz 1968). Näiden strategioiden lisäksi on Wrightin mukaan olemassa myös kolmas, rikkova (ruptural) strategia, jolla Wright viittaa klassiseen vallankumoukselliseen ideaan, jonka mukaan yhteiskunnallinen muutos toteutetaan "rikkomalla" vanhat yhteiskunnalliset instituutiot ja rakentamalla uusia niiden tilalle. Rikkovaan strategiaan Wright ei juurikaan usko.

Wright painottaa erilaisten tässä ja nyt kapitalismin sisällä ja sen "raoissa" toteutuvien käytäntöjen ja hankkeiden merkitystä yhteiskunnallisessa muutoksessa. Hän ajattelee olevan mahdollista toteuttaa antikapitalistista käytännön logiikkaa jo kapitalismin sisällä. Tämän ratkaisun mahdollistaa hänen erityinen tapansa hahmottaa kapitalistisen yhteiskunnan perustavaa luonnetta huokoisena, ristiriitaisia elementtejä sisältävänä kokonaisuutena. Wrightille kapitalismi ei ole mikään kaiken sisäänsä sulkeva totaliteetti, josta ei voisi olla ulospääsyä muuten kuin siten, että kapitalismi romahtaisi täysin. Kapitalismi, kuten mikä hyvänsä yhteiskunta- tai talousjärjestelmä, on aina "huokoinen", sen sisällä on jo ei-kapitalistisia käytäntöjä ja sen sisälle voidaan luoda myös antikapitalistisia käytäntöjä. Wrightin mukaan kaikki talousjärjestelmät ovat lopulta hybridejä (Wright 2010b, 367). Tämä koskee sekä kapitalismia että Wrightin tavoittelemaa todellista utopiaa, "sosiaalista" sosialismia.

Wrightin sosialismiin siirtymisen strategia korostaa tätä kaikkien yhteiskuntien perustavaa "epäpuhtautta". Mikään yhteiskuntamuoto ei ilmene maailmassa puhtaana, ristiriidattomasti. Kapitalistinen yhteiskunta ei ole olemassa missään puhtaana, vaan kaikkialla se sisältää ei- ja antikapitalistisia sekä sosialistisia elementtejä. Kaikki tällä hetkellä todella olemassa olevat järjestelmät ovat kapitalististen, etatististen ja sosialististen muotojen kompleksisia konfiguraatioita. Tämä koskee Wrightin mukaan sekä valtiollisen tason taloutta että yritysten sisäistä rakennetta. Esimerkiksi kapitalistinen yritys, jolla on vahvat työläisneuvostot, yhdistää kapitalismiin sosialistisia elementtejä. Näitä elementtejä yhdistää myös työläisosuuskunta, kun se palkkaa työntekijöitä. 
(Wright 2010b, 367.) Kapitalistisen yhteiskuntamuodon tosiasiallisen epäpuhtauden korostaminen perustelee myös Wrightin näkemyksiä siitä, millaisia antikapitalistisia strategioita hän kannattaa: sosialismiin siirtymisen strategialle on keskeistä sosialististen suhteiden vahvistuminen suhteessa kapitalismiin ja etatismiin.

Wrightin mukaan on analyyttisesti hyödyllistä määritellä kapitalismi, etatismi ja sosialismi kolmeksi erilliseksi rakennetyypiksi, joita erottaa taloudellista toimintaa organisoiva vallan muoto, vaikka mikään konkreettinen, todellinen talousjärjestelmä ei voi olla näistä mitään puhtaasti. Hybriditapausten yhteydessä talousjärjestelmän kutsuminen vaikkapa kapitalistiseksi merkitsee järjestelmässä dominoivan valtamuodon identifioimista. Yritys on kapitalistinen, mikäli siinä dominoiva valtamuoto on ensisijaisesti taloudellinen: mikäli taloudellisten resurssien käyttö ja allokaatio tapahtuu ensisijaisesti taloudellisen vallan harjoittamisen kautta ja mikäli tämä on dominoiva valtamuoto suhteessa taloudelliseen toimeliaisuuteen. Tällaisilla ajatuksilla on Wrightin mukaan kriittisiä implikaatioita yhteiskunnallisen muutoksen ymmärtämiselle. Emansipatorista yhteiskunnallista muutosta ei tule tarkastella hänen mukaansa ensisijaisesti binäärisesti siirtymänä järjestelmästä toiseen, vaan pikemminkin siirtymä järjestelmästä toiseen täytyy paikantaa muutoksiin yhteiskuntahybridin sisäisissä valtasommitelmissa. Kapitalismin sisälle, sen huokosiin, voidaan rakentaa sosialismin alkeissoluja, ja sosialistisen politiikan on tarkoitus vahvistaa ja laajentaa kapitalismin sisällä ja sen "rakoihin" kehittyviä sosialistisia suhteita ja käytäntöjä. (Wright 2010b, 367.)

Vaikka tällainen raottava strategia oli Wrightille aina hyvin keskeinen, kehittyvät antikapitalistista strategiaa koskevat mietteet eteenpäin erityisesti hänen myöhäisimmässä tuotannossaan. Erilaisten strategioiden luokittelut täsmentyivät. Esimerkiksi vuoden 2015 helmikuussa sosialistilehti Jacobinissa julkaistussa tekstissään Wright erittelee edellä mainittujen kolmen antikapitalistisen strategian sijaan neljä strategiaa: kapitalismin murskaaminen (smashing capitalism), kapitalismin kesyttäminen (taming capitalism), kapitalismista pakeneminen (escaping capitalism) ja kapitalismin rapauttaminen (eroding capitalism). Näistä uusista strategiakategorioista kapitalismin murskaamisen strategia näyttäisi olevan analoginen (joskaan ei välttämättä identtinen) teoksessa Envisioning Real Utopias esitellyn rikkovan strategian kanssa. Kapitalismin kesyttäminen puolestaan näyttäisi olevan samansuuntainen aiemman 
symbioottiseksi kuvaillun strategian kanssa. Viimeinen, kapitalismin rapauttamista korostava strategia puolestaan on selvästi eteenpäin kehitelty version aiemmasta raottavasta strategiasta.

Kapitalismin pakenemisen strategia on kuitenkin kokonaan uusi. Sillä Wright (2015) viittaa hyvin monenlaisiin ilmiöihin aina 1960-luvun hippien turn on, tune in and drop out -tyyppisestä ajattelusta erilaisiin uskonnollisiin ja elämäntapayhteisöihin, jotka pyrkivät parhaansa mukaan vetäytymään kapitalistisen järjestelmän vaikutuspiiristä omaehtoisilla yhteisöllisillä järjestelyillä. Erilaiset pyrkimykset "hypätä pois oravanpyörästä" ovat nimenomaan pakenemista kapitalismista. Suomessa erilaiset ekokylät sekä vaikkapa Lasse Nordlundin ja Maria Dorffin elämäntapakokeilu Valtimolla (ks. Nordlund \& Dorff 2014) edustavat tämäntyyppistä strategista orientaatiota.

Wrightin viimeiseksi jäänyt teos How to Be an Anticapitalist in the 21st Century (2019) kehittää strategioiden erittelyjä edelleen. Murskaavan, kesyttävän ja pakenevan strategian lisäksi Wright (2019, 38-64) erittelee myös purkavan (dismantling) ja vastustavan (resisting) strategian. Purkavalla strategialla Wright viittaa sellaiseen antikapitalistiseen toimintaan pyrkii ylhäältä päin, valtion tasolta lähtien asteittain purkamaan kapitalistisia instituutioita ja yhteiskunnallisia suhteita sekä korvaamaan niitä sosialistisilla. Vastustava strategia puolestaan tarkoittaa lähinnä erilaisia kapitalismista koituvien haittojen torjumista. Siinä ei pyritä valtiovallan kaappaamiseen vaan lähinnä vastustamaan kapitalististen suhteiden vaikutusta ihmisten välisiin suhteisiin ja protesteillaan vaikuttamaan eliittien ja kapitalistien käyttäytymiseen. Tällaista strategiaa noudattavat esimerkiksi sellaiset ympäristöliikkeen toimijat, jotka pyrkivät protesteillaan vaikuttamaan päättäjiin, jotta ilmastokriisiä saataisiin hillittyä.

Rapauttavan strategian Wright asettaa jälleen edellä mainittujen strategioiden oheen, mutta ei niinkään omaksi kategoriakseen vaan yhdistelmäksi useita kategorioita. Se on yksi mahdollinen "strateginen konfiguraatio" (Wright 2019, 53-58), jossa korostuvat kapitalismin murskaamista lukuun ottamatta kaikki strategiset ulottuvuudet. Kapitalismin rapauttamisen strategiassa pyritään paitsi vastustamaan kapitalismia erilaisin protestein, kesyttämään kapitalismia erilaisin valtiollisin reformein sekä purkamaan kapitalistisia suhteita ja luomaan niiden tilalle sosialistisia yhteiskunnallisia suhteita, myös pakenemaan kapitalistisia suhteita ja kapitalismin vaikutusvaltaa jokapäiväisessä 
elämässä luomalla toisin toimisen tiloja ja erilaisia vastakäytäntöjen logiikoita. Se pyrkii yhtä aikaa sekä neutralisoimaan kapitalismin aiheuttamia haittoja että ylittämään kapitalistiset rakenteet kokonaan. Jos kapitalistinen yhteiskunta käsitetään eräänlaiseksi "peliksi", merkitsee kapitalismin rapauttamisen strategia paitsi tietynlaisia siirtoja tuon pelin sisällä, myös itse pelin sääntöjen muuttamista.

\section{Lopuksi}

Wrightin ajattelu ei koskaan jämähtänyt paikalleen vaan hän jatkoi uusien käsitteiden kehittelyä loppuun asti. Tämän näkyy etenkin teosten Envisioning Real Utopias ja How to Be an Anticapitalist in the 21st Century eroissa. Vaikka jälkimmäisestä teoksesta piti tulla vain edellisen jatko-osa tai tiivistelmä, osoittavat siinä esiintyvät uudet analyyttiset jaottelut Wrightin loppuun asti kantanutta itsekriittisyyttä ja avoimuutta muiden kritiikeille.

Sellaistakin kritiikkiä, jota Wright ei oikein ymmärtänyt, on esiintynyt. Etenkin Russell Jacobyn hyökkäys Wrightin utopia-ajattelua kohtaan Dissident-lehdessä vuonna 2011 sai Wrightin ymmälleen. Jacobyn (2011) kritiikkiä on paikoin vaikea ymmärtää, koska se takertuu usein enemmän Wrightin tyyliin kuin hänen ajatustensa sisältöön. Yksi Jacobya selvästi harmittava asia on Wrightin ajattelun tietynlainen epähistoriallisuus. Hänen mukaansa Wright ei juurikaan osoita historiallista tuntemustaan utopioista ja utooppisesta ajattelusta eikä myöskään tarpeeksi tarkasti viitteistä ajattelunsa lähteitä. Wrightin itsensä mukaan syytöksessä epähistoriallisuudesta voi olla jotain perää, mutta toisaalta hän ei kokenut itse olevansa varsinainen aatehistorioitsija tai kokenut aatehistorialla olevan annettavaa hänen teoretisoinneilleen, vaan korosti oman käsitetyönsä olevan enemmänkin ideoiden analyyttista rekonstruktiota kuin ideoiden historiallisen alkuperän kartoittamista (Wright, Lakkala \& Pyykkönen 2018).

Wrightin teoriaa on kritisoitu myös feministisestä näkökulmasta siitä, että hän käsitteellisesti erottaa taloudellisen aktiviteetin omaksi alueekseen yhteiskunnassa. Tällainen käsitteellinen ratkaisu on esimerkiksi sosiologi Ruth Levitasin (2013) mielestä omiaan sivuuttamaan muun muassa monenlaisia hoivatyön muotoja. Tämän lisäksi Wrightia on kritisoitu myös tämän Marxia 
koskevasta tulkinnasta, jossa Marxin poliittisen taloustieteen kritiikki ymmärretään puhtaan deterministisesti (Ruccio 2011). Wrightia on kritisoitu myös siitä, että hän tarkastelee useita todellisiksi utopioiksi katsomiaan hankkeita ja kokeiluja toisistaan erillisinä, vaikka usein tällaiset hankkeet etenevät yhdessä osana laajempaa liikehdintää (Borowiak 2012).

Näistä kritiikeistä huolimatta uskon Wrightin todellisten utopioiden projektin jatkuvan tulevaisuudessakin. Tämä näyttää varsin todennäköiseltä, sillä Wrightin kotiyliopisto Wisconsin-Madisonin Havens Wright -keskus tulee myös tulevaisuudessa jatkamaan The Real Utopias -projektia. Suomessa todellisten utopioiden tutkimus saanee uutta puhtia, kun Jyväskylän yliopiston vuosina 2017-2019 toimineen Utopia metodina. Yhteiskunnallisen muutoksen mahdollisuuksien artikulaatioita -hankkeen Envisioning Real Utopias -käännös saadaan julki. Tämän käännöksen myötä sopii toivoa, että myös empiirinen tosimaailman utopiahankkeiden tutkimus voisi edetä Suomessa.

\section{Viitteet}

I) Osallisuustaloudella tarkoitetaan lyhyesti sanottuna sellaista talousjärjestelmää, jossa tärkeimmät instituutiot ovat demokraattisia yhteisöjä: työntekijöiden johtamia yrityksiä ja kuluttajayhdistyksiä. Yritykset ja yhdistykset päättävät talouden tuotannosta ja kulutuksesta osallistavassa, demokraattisessa suunnitteluprosessissa. Ks. esim. Jauhiainen \& Mäkinen (2018).

\section{Lähteet}

Bloch, Ernst. 1985. Ennakoitu todellisuus - mitä on utooppinen ajattelu ja mitä se saa aikaan. Suom. Raija Sironen. Teoksessa Keijo Rahkonen \& Esa Sironen (toim.) Utopia, luonto, uskonto. Helsinki: Kansan Sivistystyön Liitto, 22-33. Bloch, Ernst. 1986. The Principle of Hope. Volume One. Cambridge: The MIT Press.

Borowiak, Craig. 2013. Scaling up Utopias: E.O. Wright and the Search for Economic Alternatives. New Political Science, 34:3, 359-365. 
Burawoy, Michael. 2019. Afterword. Teoksessa How to be an anticapitalist in the 21st century. [E-kirja] London: Verso, 147-157.

Franks, Benjamin. 2018. Prefiguration. Teoksessa Benjamin Franks, Nathan Jun \& Leonard Williams (toim.) Anarchism. A Conceptual Approach. New York/ London: Routledge, 28-43.

Gorz, André. 1968. Reform and Revolution. Socialist Register. Vol. 5, 111-143. Hahnel, Robin ja Wright, Erik Olin. 2016. Alternatives to Capitalism: Proposals for a Democratic Economy. [E-kirja] London: Verso.

Jacoby, Russell. 2011. Real Men find Real Utopias. Dissent Magazine. Winter 2011.

Jauhiainen, Antti ja Mäkinen, Joona-Hermanni. 2018. Osallisuustalous - visio demokraattisesta taloudesta. Teoksessa Minna Mentula, Keijo Lakkala, Simo Suominen \& Hanna Era (toim.) Utopia työkaluna. Irti vaihtoehdottomuuden valheesta. Helsinki: Demokraattinen Sivistysliitto, 89-96.

Kinna, Ruth. 2016.Utopianism and Prefiguration. Teoksessa S.D. Chrostowska \& James D. Ingram (toim.) Political Uses of Utopia. New Marxist, Anarchist, and Radical Democratic Perspectives. New York: Columbia University Press, 198-215.

Levitas, Ruth. 2013. Some varities of utopian method. Irish Journal of Sociology. Volume 21. Issue 2, 41-50.

Mannheim, Karl. 1979. Ideology and Utopia. An Introduction to the Sociology of Knowledge. London/Henley: Routledge \& Kegan Paul.

Monticelli, Lara. 2018. Embodying Alternatives to Capitalism in the 21stCentury. triple-C: Communication, Capitalism \& Critique. Journal for a Global Sustainable Information Society. Vol. 16. No. 2 (2018), 501-517.

Nordlund, Lasse ja Dorff, Maria. 2014. Elämämme perusteista. Pohdintoja työstä, rahasta ja energiasta omavaraisen elämänkokemuksen valossa. Siuro: Palladium Kirjat.

Rawls, John. 1999. The Law of Peoples: with "The Idea of Public Reason Revisited". Cambridge, Massachusetts: Harvard University Press.

Ruccio, David F. 2011. Envisioning Real Utopias, Erik Olin Wright, London: Verso, 2010. Historical Materialism. Vol. 19 (4), 219-227. 
Wright, Erik Olin. 1971. Transcript of Utopia \& Revolution Seminar. Graduate Theological Union. Berkeley, California. January 1971. Prepared by Erik Olin Wright.https://ssc.wisc.edu/ wright/Utopia\%20\&\%20Revolution.pdf [Luettu 16.5.2020]

Wright, Erik Olin. 1985. Classes. London: Verso.

Wright, Erik Olin. 2010a. Perustulo sosialistisena projektina. Teoksessa Ruurik Holm \& Laura Tuominen (toim.) Peruste 1/2010. Omistus. Helsinki: Vasemmistofoorumi, 72-85.

Wright, Erik Olin. 2010b. Envisioning Real Utopias. London: Verso.

Wright, Erik Olin. 2012. Transforming Capitalism through Real Utopias. American Sociological Review. XX(X), 1-25.

Wright, Erik Olin. 2015. How to Be an Anticapitalist Today? Jacobin.12.2.2015. https://www.jacobinmag.com/2015/12/erik-olin-wright-real-utopiasanticapitalism-democracy/ [Luettu 16.5.2020]

Wright, Erik Olin. 2016. How to be an anticapitalist in the the 21st century. The Journal of Australian Political Economy. No. 77. Winter 2016: [5]-22.

Wright, Erik Olin. 2019. How to be an anticapitalist in the 21st century. [E-kirja] London: Verso.

Wright, Erik Olin, Lakkala, Keijo ja Pyykkönen, Miikka. 2018. Sosialismi ja utopia - vastausvuorossa Erik Olin Wright. Niin \& näin. 1/18. https://netn. fi/artikkeli/sosialismi-ja-utopia-tanaan-vastausvuorossa-erik-olin-wright [Luettu 16.5.2020] 